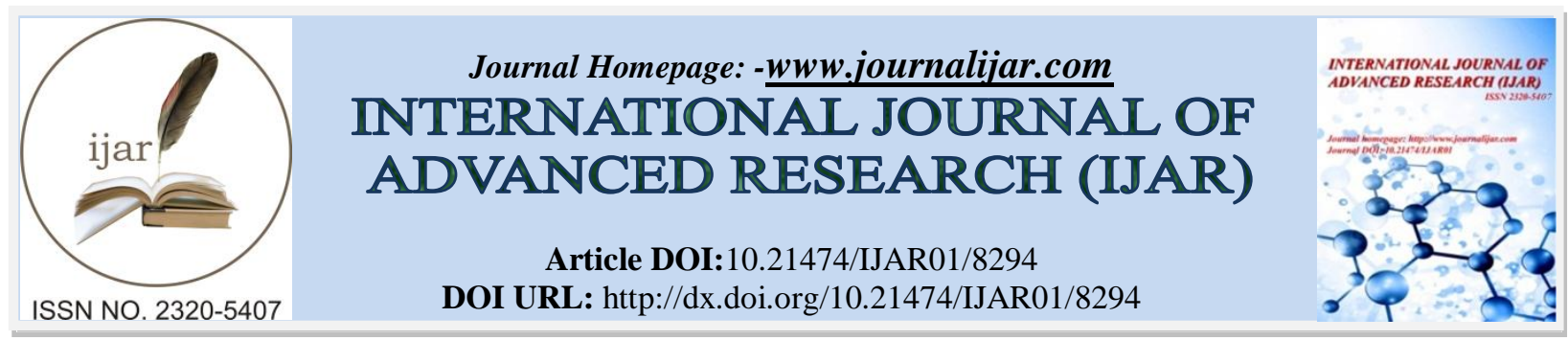

RESEARCH ARTICLE

\title{
ADOPTION OF SMALL GROUP TECHNIQUE ON STANDARD SEVEN LEARNERS' ACHIEVEMENT IN ENGLISH COMPOSITION WRITING IN PUBLIC PRIMARY SCHOOLS IN KISUMU COUNTY, KENYA.
}

Hellen W. Kamau.

Department of Educational Communication \&Technology, University of Nairobi, Kikuyu Camps.

\section{Manuscript Info}

Manuscript History

Received: 01 November 2018

Final Accepted: 03 December 2018

Published: January 2019

Keywords:

Small group techniquie, Three minutes technique; Buzz technique; Revised group technique.

\section{Abstract}

Small group is hugely rewarding, both for facilitator and learners. This pedagogy is the best teaching skill worth nurturing and defending. Small group offers flexibility, interaction, flexibility, reflexibility. and engamement. To teach standard seven learners in English composition writing offers the learners opportunity to be able to work well in the groups where behaviour, collaboration and communication is natured. The study was guided by the objectives: To examine the influence of small groups' technique on learners' achievement in composition writing skills in public primary schools in Kisumu County. Drawn from Lev Vygotsky( $1962 ; 1978)$ the vision of pedagogy is based on the idea of learning as an interactive, social process, within which the facilitator directs the transition of the learners into the Zonal prominal development in order to cultivate new knowledge in order to cultivate new knowledge . Pre-test Post-test nonequivalent groups research design was adopted, sample size of 292 was drawn from 6 teacher of English, 6 head teacher and standard seven pupils in public schools. Data were collected via questionnaire, observation schedule and check list. Analysis was done using descriptive statistics. The study found that for small group learning technique: revised strategy is moderately used $(m=3.80$ with SD of 2.960) buzz strategy is moderately $(m=3.40$ with SD of 2.106) used in teaching composition and three minutes strategy is highly used (M=4.20 with SD of 2.269) in composition teaching. The computed $\mathrm{z}$ values for brainstorming technique elements revealed a $\mathrm{z}$-statistic value higher than the $\mathrm{z}$ Critical value and $\mathrm{P}$-value less than 0.05 . Thus, the study rejected the entire five Null hypotheses as there was a statistically significant relationship between: individual group technique, whole class technique, small group technique, round robin technique and relay technique; and learners' achievement in composition writing skills in public primary schools in Kisumu County. The study recommended that similar studies to be carried out using inferential statistics, especially multiple regression analysis to assess how the individual strategies of brainstorming teaching technique contribute to overall learners learning achievements. Other researches can use the Humanist child development theory to carter for the concerns of a paradigm shift to the thinking about holistic development of the learners, the policy makers and implementers 
ministry of Education and Kenya National Examination Council, to address the use of inquiring-based learning in order to provoke criticalthinking in learners as the new (CBC) get rooted to curb the negative attitude of embracing change of teaching for life and not for exams.

Copy Right, IJAR, 2018,. All rights reserved.

\section{Introduction:-}

The third technique is small group learning technique, which offers learners a chance to develop skills on how to relate, handle issues and relay messages .It is a vital element in the outside world. Small group technique is characterized by language behaviour. Although the term 'small group learning', also referred to as tutorial, is the key element of small group facilitation, teaching is usually connected with a chain of small discussions which is problem based with very unique methods on how the content is discussed, i.e. discussing and giving feedback. According to Qatari (2010) there is no supernatural number that defines a group as a Small group. The number of participants varies with the population of learners. However, an ideal small group would comprise of 10 participants (Almaghawry, 2012).

KCPE Mean Scores in English Language and Composition for Kisumu County Between 2014 to 2017

\begin{tabular}{|l|l|l|l|l|l|}
\hline \multirow{2}{*}{ Category } & \multicolumn{5}{c|}{ Mean Score Performance } \\
\cline { 2 - 6 } & $\mathbf{2 0 1 3}$ & $\mathbf{2 0 1 4}$ & $\mathbf{2 0 1 5}$ & $\mathbf{2 0 1 6}$ & $\mathbf{2 0 1 7}$ \\
\hline Language & 53.06 & 47.62 & 49.98 & 50.52 & 47.62 \\
\hline Composition & 41.90 & 41.45 & 41.38 & 40.25 & 39.60 \\
\hline
\end{tabular}

Source: The Kenya National Examination Council (2017).

\section{Statement Of The Problem}

In Kenya the national Examination Council has shown Primary schools learners have over the years performed poorly as indicated in the (KNEC Examination Report 2013-2017 demonstrated on the table above. Therefore, the delivery of the curriculum, monitoring and examination needs to be looked into to understand exactly where the gap is. This study has observed that the approaches taken by the teachers to deliver in Kisumu County have generally contributed to the overall results in National examinations (field observation). This study suggests that teachers of English while handling composition writing have to embrace different methods to use when teaching writing skills.

The Kenyan primary syllabus has emphasized on the resources, pedagogy of handling each component that translate to the overall performance of English language. The table shown above has shown that the grammar is better performed then the composition writing skills. Both have to be handled well since they both add up to the final grade for English as a whole paper. This is wanting since all instruction and assessment is done through the language despite its poor performance expect Kiswahili which performance well in insha writing than sarufi as evidence stipulated in (the KNEC) Examination Report 2013 -2017.

The new curriculum (CBC) has a lot of emphasis on Literacy activities especially to address the four skills which are very vital in the overall performance of English language. The brain storming technique has not been elaborated and comprehensively be looked at as a teaching strategy that can enhance critical thinking, idea generation to boost the writing skills by the stalk holders ,the Ministry of Higher Education and Science and technology, The Kenya institute of curriculum development. Therefore, this study provides information on the influence of brain storming technique on standard seven learner's achievement in English composition writing in public primary schools in Kisumu County, Kenya. This study has demonstrated the need and urgency of its adoption and implementation.

\section{Review of related literature}

\section{Small group's technique and learners' composition writing skills}

A small group teaching can involve a wide combination of exercises, including courses, workshops, instructional exercises, tutor-less or student-led instructional exercises, labs, problem-based learning (PBL) groups, and a scope of online arrangements of small groups of students adapting together. Small group teaching may likewise occur inside bigger gathering training when students are separated into smaller numbers for group work. Oxley and Dennick (2004), for instance, draw on Booth (1996) to propose that when all is said and done a 'small' group should 
comprise of somewhere in the range of five and eight individuals, with six an ideal number for tutor-style small group teaching. This type of learning allows learners to grow problem resolving, personal, presentational and communication skills, all these are useful to life outside the classroom. Writing is one of the four skills that should be learnt and mastered in language learning. According to (Hanna, Taqai and Nowieyah, 2014) the instructor took notes of her observation of the formation of and participation in group work. It was found that the students who worked in groups did not improve. However, most students reported that they enjoyed the tasks and would like to work in a group more often. The method of forming a group also seemed to affect learning. It was found that social and academic variables of age and GPA affected the formation, engagement and results of group work.

Bonita, (2012) reckons there is more commitment among the groups to make final decision and more dysfunctional brainstorming. Social academic variables, method of formation of groups affected learning, learners who worked in groups never improved, studies report that they had fun doing the activity in groups.. Barnett and Clark (2008) suggested advantages of facilitating higher order thinking skills, motivating learners and fostering reading comprehensions. Patel and Jain (2008) further states that writing is a kind of language behaviour, unlike a picture. This presents sounds of language over visual signs. Writing maybe significant for one group of learners but not so much important for others. Writing is a fundamental type of learning language since it offers very good means of foxing the vocabulary, sentences pattern and spelling. Writing is competently learnt when exercises in writing parallel it.

Martal (2014) on his research, found out that, it is hypothesized that concrete knowledge of research based instructional methods that can be used in co-teaching situation may reduce rates of teacher frustration and attrition, and will improve academic and behavioural performance of students in a variety of settings and imagined that the methodology of based instruction can be in cooperated in order to cut down the teacher disappointment and wearing away.

Patel \& Jain (2008) put more emphasis that writing is a type of linguistic activity, an image is not. It depicts the sounds of verbal communication through visual symbols. Writing may possibly be very significant for one cluster of learners but much less essential for others. Writing is a fundamental type of knowledge than verbal communication because it offers better means of fixing the words, spelling, and sentences pattern. Writing is most powerfully achieved when exercise in writing parallels practice in the other skills. It provides an excellent consolidating activity.

These theoretical and philosophical underpinnings are often left understood in the more direct 'how-to' sequence of events that dominates academic writing about small group teaching, but it is significance pausing here to think about the deeper question of why we teach in small groups. Small group teaching provides an alternative approach to teaching and learning than that obtainable by the more traditional didactic master-apprentice / teacher-student model. Much of the academic creative writing about small group teaching heralds from psychology and associated disciplines, and in this respect the work of the Russian psychologist Lev Vygotsky $(1962 ; 1978)$ has distinctly influenced more recent thinking about why small group teaching is 'good' pedagogically.

Vygotsky vision of pedagogy is based on the idea of learning as an interactive, social process, within which the teacher facilitates the move of the learner into 'zones of proximal development' in order to cultivate new knowledge. That is, the role of the instructor is to facilitate rather than to order the nature of what is being learned, meaning that students have an active role in this process. The teacher provides the 'scaffolding' around which students are able to construct their own learning, building on prior knowledge. For this reason, this approach to pedagogy is often referred to as collaborative learning, because it is centred around the interactions between teachers and students, somewhat than seeing learning as a one-way interaction where knowledge is imparted from the teacher to the student. Within what is known unreliably as the socio-cultural, cultural-historical or 'constructivist' tradition in psychology and educational research, this fundamental principal remains important to the idea of 'good' teaching tradition in general. In turn, it is this social, interactive approach to learning that is at the heart of all 'good' small group teaching.

The narrative on small group teaching from psychology also draws links between social relations and cognition (that is, how our brains develop, and how we think and learn). A 'cognitive' approach to small group teaching, building on the theories of Piaget, would suggest that learning interactively in small groups is beneficial to students because the process of debating decisions, dealing with conflict, and reconciling divergent perspectives is an essential part of 
how cognitive development takes place. This thought about cognition also underpins the notion of "cognitive elaboration by Dansereau (1988), which points out that cognitive development is based on reformulating or elaborating existing knowledge into new forms - a sort of unlearning and relearning of knowledge. According to this developmental perspective, small group teaching nurtures cognition through social interaction. Research into 'social cognition' (Levine \&Resnick 1993) also points along these lines, that cognition, while taking place individually, is inherently social in its construction. Learning in social and cultural context: perspectives from sociology and anthropology

In these different ways, perspectives from psychology generally focus on individuals in social context, exploring how the particular traits or cognitive abilities of these individuals might combine to create a particular atmosphere or dynamism within small group teaching, and in so doing influence the kind of teaching and learning taking place. In general terms, we might say that perspectives from sociology and anthropology, on the other hand, focus first and foremost on social and cultural context, and subsequently on how individuals might in their own distinctive ways reflect social structures and cultural practices in their interactions with one another. Within the sub-disciplines of the sociology and anthropology of education, social relations are from first principles considered to be key in educative processes. This means that sociological and anthropological perspectives are very useful for exploring how larger social issues of authority, ability and uniqueness might also come into the process of small group teaching (issues such as class, gender, ethnicity, and so on).

A lesser amount of study has been conducted within sociology and anthropology than among psychologists that deal with small group teaching as a practice per se. However, there exist many sociological accounts of teaching and learning upon which teachers can draw to develop and enhance their approach to small group teaching. Reading accounts of social life in educational settings can help you shed light on how broader cultural and social influences might impact on your teaching practice. An early example of this focus within anthropological research on education (in its broadest definition), for example, is Margaret Mead's work among adolescents in Western Samoa (1943). Mead argued that stereotypical Western experiences of coming of age were not universal to all humans, as posited by prominent psychologists at the time, but was instead the result of social and cultural context. Much more recently, the anthropologist Rebekah Nathan (aka Cathy Small) (2005) has written about her experiences pretending to be an undergraduate at a North American university. Nathan masqueraded as a student so that she could see university through undergraduate eyes. While ethically problematic, this serves as one account among many that can be thought-provoking for new teachers (for others, see, for example, Willis 1977; Evans 2007). Over the last century, many other social theorists have added to our understanding of how social and cultural forces profile our experiences, our interactions and our identities, particularly in educational or other institutional settings. Presentation, genuineness, authority and influence are among the vital themes in this narrative.

On the whole, then, the focus on social interactions in these different disciplinary understandings of teaching and learning fits together in a complimentary way. We might also add into the mix here the ideas of John Dewey (1916), one of the twentieth century's most influential philosophers and psychologists of education. Like the psychologists, sociologists and anthropologists above, Dewey also believed that education is a essentially social process borne of relations between students and teachers. Dewey was also predominantly interested in the how students learn through knowledge, both within specific learning encounters and in their ability to build on prior knowledge and experience to develop new knowledge. In addition to this, Dewey saw education not only as a social process, but also as a means to social change. Dewey would argue that the small group serves as an ideal context within which individuals can focus their attentions both on individual success and also on the success of the collective through democratic participation. Of relevance to why small group teaching is a good way to teach, then, is Dewey's idea that working towards both individual and group-focused goals is not only a natural and primary part of efficient pedagogy, but also the key to progressive social change.

More recent educational thinkers, such as Stephen Brookfield and Stephen Preskill (2005) have developed these facts to demonstrate the associates between relations, conversation, and promoting an independent approach to education. Of course, it is important to recognise that social dealings also involve discussions of influence and power, and that Dewey's ideal of education, when applied to small group teaching, must be reconciled with the realities of social interactions that are in their very nature asymmetrical and prone to maintaining inequitable hierarchies. We will discuss this in more detail in a moment, particularly in relation to the sociological and anthropological literature on these topics. So, the essentially 'good' thing about small group teaching is that it encourages learning through social interaction, and allows students to become actively engaged in the educative 
process. There are lots of ways of phrasing this perspective of small group teaching: Brown \& Race (1995) suggest that it is reflective of the best aspects of social learning more generally, while Jaques (1991) and Exley\&Dennick (2004) talk about a focus on content and process - both the development of substantive subject knowledge and learning valuable skills through the process of teaching and learning in small groups. However we phrase it, in practice this translates to a number of different key areas of learning and development for students in small groups.

The flexible and reflexive nature of small group teaching implies that instructors can adjust their way to deal with guidance with the end goal to meet the individual needs of understudies. Separation (that is, fluctuating one's way to deal with instructing with the end goal to meet the scholarly and social needs of individual understudies) enables instructors to focus on the particular learning and aptitudes that understudies need to create. At the point when done successfully, this individualized or customized way to deal with instructing and learning will enable understudies to create nitty gritty subject information as well as higher scholarly/scholastic aptitudes, for example, basic reasoning and investigation. In a perfect world, close to home communication with a scholarly in their field will likewise enable understudies to build up a new feeling of scholastic and additionally disciplinary personality, which will thusly encourage commitment in the substantive exercises occurring. Thus, the little gathering instructor may likewise gain specifically from understudies, and enhance his or her showing practice subsequently. As far as evaluation, the abnormal state of intelligence in little gathering instructing implies that educators can give developmental (or continuous) appraisal of advancement (otherwise called evaluation for adapting), as opposed to just concentrating on summative or end obviously/exam-type types of evaluation. Being evaluated along these lines enables understudies to effectively take part in gaining combined ground amid the way toward instructing and adapting, instead of considering appraisal to be a result of the learning background, even where last/particular examinations direct formal outcomes (Black and William 1998).

Encouraging the active participation of students in the learning process demands responsibility and organization on the part of students (and teachers), and in this respect small group teaching fosters an independent approach to learning. Emphasising the learning that takes place independently outside of contact hours can encourage students to recognise the active part that they play in the educative processes of small group teaching. At the same time, close interaction with other group members can generate a sense of community within the small group and/or a sense of shared disciplinary identity; and, quite simply, social interaction can make learning more interactive and fun. This may be particularly important for less confident students who may not participate as much in larger groups, or for those who for whatever reason seem reluctant to learn.

Part of what makes small group teaching enjoyable and effective is the flexibility that comes with teaching in a small group. Small group teaching is sometimes more flexible temporally (i.e. in terms of when the teaching takes place) and spatially (i.e. where the teaching takes place, and how this space is organized in terms of seating arrangements, resources, appropriateness for activities, etc.). Students can be encouraged to develop a sense of ownership through helping to define these spatial and temporal boundaries (Jaques 2007). Small group advocates for learners participation in class activities, sharing ideals , learners weigh pros and cons of a given situation with each other to find a solution to the problem , working in cooperation with one another , learners understand it is until and unless all put their best ,they would not be able to complete the given task competently.

Learning in groups allows the ideal of discussions, speaking, collaborating presentation, critiquing each other's work .This enhances the life skill element outside classroom. Writing is one of the four skills that should be learnt and mastered in language learning. Facilitator skills are vital and need the teacher to make sure that both the assignment is achieved and the group operation is maintained. Small group learning allows students to develop problem solving, interpersonal, presentational and communication skills, all useful to life outside the classroom.

\section{Three- minute technique}

Three minutes technique is guarded by facilitator who times the working then gives the presenters of group to present the work and others critique. Questions are used for others to respond. Learners in the groups can ask a descriptive question to the other members or respond to questions of other group members.

According to MohdMohzan Awing et.al (2013) effectiveness of induction-set is dependent on teacher's creativity and pedagogical content knowledge. As one strategy does not fit all situations, it is vital for the teacher to initiate 
creative lesson plans to attract pupils' attention. Results also suggest that the displays of positive actions towards disruptive behaviour as well as the look of praises given to pupils increased problematic behaviour in classroom. This study sought to bring insight to effective practice for promoting learning behaviour in classroom contexts. This study seeks to find out if three-minute technique can improve composition writing.

According to Fleming (2006) these topics taught using mime formed a basis of a three minute activity. Examples of some of the topics given were; lost son, an incident at a shopping centre, terrorist arrested in a mall, an argument at the market and friends birthday party. Learners were given five minutes to prepare and present the mime to the class. Learners performed their mime in turns as other students listened, and took notes on major points from the performance. The teacher prepared an impromptu test and gave it to the class to test their acquisition of learnt concepts. Furthermore, Carter (2002) supported the use of mime in providing evaluative exercises and boosting learner achievement in learning the English language. Additionally, the study conducted by Barbu and Lucia (2007) advocated the use of mime in the classroom to enhance acquisition of content in parts of speech, for example, nouns, pronouns, verbs, and adjective, hence learner achievement is improved.

According to Hanna, Taqai and Nowieyah (2014) the facilitator observed and assessed what was taking place in all the participants. Majority reported that the working in groups did not yield much however the learners were excited in the working atmosphere .Formations of the groups affected the learning, involvement and achievements due to the social and academic variables of age and GPA. David et al (2013) in the skill of on writing on Small group teaching puts more strength on the truth that it is more satisfying to facilitators and learners. Thus this methodology is recognized as the best to be embraced by higher Education and worth instilling and nurturing. In addition, emphasis on how teachers need to use motivation to learners these is effective as learners' participants in the group work. They further reveals that teachers especially in shaping behaviour of learners are vital in the classroom scenery.

\section{Revised Group Technique}

Bonita (2012) reckons there are more committee men among the groups to make final decision and more dysfunctional brainstorming. Social academic variables, method of formation of groups affected learning, learners who worked in groups never improved, studies report that they enjoyed the tasks and would like to work in groups more often. Barnett and Clark (2008) suggested advantages of facilitating higher order thinking skills, motivating learners and fostering reading comprehensions. In this study, Wiwiek et al (2001) found out that, small group working technique could improve the students' active participation and their reading comprehension. This study seeks to investigate the influence of revised strategy in composition writing

\section{Buzz Group Technique}

A study that investigated the influence of buzz group technique in composition writing was conducted by Mash (2015). The study explored the functioning of buzz group strategy in bettering learners' energy and writing skill of hortatory exposition text at the eleventh-grade students of MAAC-KHORIYYAH Semarang in academic year of $2014 \backslash 2015$ and to know the enhancements of students and writing skill of hortatory exposition text after being taught using Buzz Group Technique.

Buzz group technique can enhance student activeness and writing skills of hortatory exposition text. The result of the study showed that students enhance their activeness and writing skills by using buzz group technique.

\section{Methodology:- \\ Introduction}

The chapter explains the methodology approach that was adopted to provide answer to the research questions. It discussed in details the adopted research design, target population, sample size and sampling procedure, data collection tools and pilot test. The chapter also includes discussion of data analysis method and test statistics.

\section{Design Used}

\section{The article adopted a Non-equivalent control group with pre and post- test research design.}

Cohen, Manion\& Morrison (2007) asserts that non - equivalent control group design is commonly used in education research where participants have homogenous characteristics and in a class within a class where learners are naturally organized in groups. The design is ideal in classroom experiments when experimental and control groups are such naturally assembled groups as intact classes, which may be similar. As argued by Bell (1993) that non- 
equivalent control group with pre and post-test design enables researchers to obtain information from a representative selection of the population and from that sample present findings as a pointer trends. The design, thus, enabled the study to assess influence of brainstorming technique, as an experiment group, on learner's achievements in composition writing in relation to control group. Heiman (1999) a statistical analysis of significance based on this design, with analysis of variance (ANOVA) or t-test.

\section{Conclusion:-}

For small group learning technique, the study concludes that revised strategy and buzz strategy are moderately used in teaching composition in public primary schools. Three minutes strategy and small group are highly used in teaching composition in public primary schools. In addition, small group technique and small group technique positively influence learners' achievement in composition writing skills in public primary schools

\section{Recommendations:-}

Objective Three: Examine the Influence of Small Groups' Technique on Learners' Achievement in Composition Writing Skills in Public Primary Schools in Kisumu County

The third objective sought to examine the influence of small group technique on learners' achievement in composition writing skills. The questionnaire for teachers of English Part G (questions 1-12) and learners questionnaire part $G$ (questions 1-12) provided responses for this objective. The hypothesis tested under this objective was, $\mathrm{HO}_{3}$ : (There is no

statistically significant difference between small group technique and learners' achievement in composition writing in public primary schools in Kisumu County). The objective was analysed in three stages using various likert scale ratings.

\section{How Often Teachers of English use Small Group Technique Teaching Strategies}

The first stage of analysis sought to determine how often teachers of English embrace learning strategies of small group technique in teaching composition writing in public schools in Kisumu County. Teachers of English were asked to rate their agreement on a four point likert scale of 1-4, with 1 denoting Never (N), 2 denoting Seldom (S), 3 denoting Some of the Time (SOT) and 4 denoting Most of the time (MOT). Results are discussed below.

\section{How Often Teachers of English Use Revised Strategy}

Findings of how often revised strategy is used in teaching English composition in public primary schools is shown in Table 4.29.

Table 4.1:-Use of Revised Strategy

\begin{tabular}{|l|l|l|}
\hline Response Category & Frequency & Percent \\
\hline Most of the time & 1 & 16.67 \\
\hline Some of the time & 2 & 33.33 \\
\hline Seldom & 2 & 33.33 \\
\hline Never & 1 & 16.67 \\
\hline Total & $\mathbf{6}$ & $\mathbf{1 0 0 . 0 0}$ \\
\hline
\end{tabular}

Findings from Table 4.1 show that $1(16.67 \%)$ teacher of English responded that she uses revised strategy in teaching composition writing most of the time, $2(33.33 \%)$ responded that they use revised strategy some of the time, $2(33.33 \%)$ responded that they seldom use revised strategy in teaching English composition writing and, 1 $(16.67 \%)$ teacher of teacher of English responded that he never uses revised strategy in teaching composition writing. The mean and standard deviation rating for use of revised strategy showed $\mathrm{M}=2.50$ and $\mathrm{SD}=0.960$ which implies that revised strategy is some of time used in teaching English composition in public primary schools.

\section{How Often Teachers of English Uses Buzz Strategy}

Present analysis sought to find out how often teachers of English use buzz strategy in teaching English composition writing in public primary schools. Findings are presented in Table 4.30.

Table 4.2:-Use of Buzz Strategy

\begin{tabular}{|l|l|l|}
\hline Response Category & Frequency & Percent \\
\hline Most of the time & 2 & 33.33 \\
\hline
\end{tabular}




\begin{tabular}{|l|l|l|}
\hline Some of the time & 2 & 33.33 \\
\hline Seldom & 1 & 16.67 \\
\hline Never & 1 & 16.67 \\
\hline Total & $\mathbf{6}$ & $\mathbf{1 0 0 . 0 0}$ \\
\hline
\end{tabular}

Finding from Table 4.2 show that 2 (33.33\%) teachers of English responded that they most of the time use buzz strategy in teaching composition writing, $2(33.33 \%)$ responded that they some of the time use buzz strategy in teaching English composition writing, 1 (16.67\%) responded that she seldom uses buzz strategy and $1(16.66 \%)$ teacher of English responded that she never uses buzz strategy. Mean and standard deviation rating for use of buzz strategy revealed $\mathrm{M}=2.833$ and $\mathrm{SD}=1.960$. These findings imply buzz strategy is some of the time used in teaching composition writing in public primary schools in Kisumu County.

How Often Teachers of English Use Three Minutes Strategy

Present analysis sought to determine how often teachers of English use Three Minutes strategy in teaching composition writing in public primary schools. The results are shown in Table 4.2.

Table 4.3:-Use of Three Minutes Strategy

\begin{tabular}{|l|l|l|}
\hline Response Category & Frequency & Percent \\
\hline Most of the time & 2 & 33.33 \\
\hline Some of the time & 2 & 33.33 \\
\hline Seldom & 0 & 0.00 \\
\hline Never & 2 & 33.33 \\
\hline Total & $\mathbf{6}$ & $\mathbf{1 0 0 . 0 0}$ \\
\hline
\end{tabular}

Finding for Three Minutes strategy shown in Table 4.3 revealed that $2(33.33 \%)$ teachers of English most of the time use Three Minutes strategy of small group technique, 2 (33.33\%) teachers of English use Three Minutes strategy some of the time, and 2 (33.33\%) teachers never use Three Minutes strategy. Mean and standard deviation rating of use of Three Minutes strategy revealed $M=2.66$ and $\mathrm{SD}=1.269$. This finding reveals that Three Minutes strategy is seldom used in teaching composition writing in public primary schools in Kisumu County. These findings corroborates with Wiwiek et al (2010). Their study titled "improving the tenth-grade students reading comprehension achievement through small group working technique" revealed that Three Minutes and small group working technique improve the student's active participation and their reading comprehension, and this could be the justification for the rise in use of this technique.

\section{Small Group Technique Influence on Learners Achievement}

This phase of analysis sought to determine how small group technique of brainstorming influences learners' achievement. Results for learner respondents rating, on a five likert point scale (1=strongly disagree, $2=$ Disagree, $3=$ Indifferent, 4=Agrees and 5=Strongly Agrees), of the extent to which they agreed with the provided questions are discussed below.

\section{Revised Strategy}

The study sought to find out how use of revised strategy influences learners achievement in composition writing. Three indicators were assessed and Findings are presented in Table 4.32.

Table 4.4:-Revised Strategy Influence on Learners Performance

\begin{tabular}{|c|c|c|}
\hline Strategy Statements & Mean & Std. Dev \\
\hline I normally use good expressions while writing. & 4.14 & 1.341 \\
\hline I write as if am having a conversation with another person. & 3.07 & 1.039 \\
\hline $\begin{array}{l}\text { While writing, I vary my punctuation marks on specific } \\
\text { sentences and paragraph. }\end{array}$ & 3.98 & 1.122 \\
\hline $\begin{array}{l}\text { While writing, I put words and sentences to make good } \\
\text { paragraphs. }\end{array}$ & 4.23 & 1.479 \\
\hline Average Score & 3.86 & 1.245 \\
\hline
\end{tabular}

Table 4.4 findings revealed that learners agreed $(\mathrm{M}=4.14$ and $\mathrm{SD}=1.341)$ they can normally use good expression while writing. Learners were indifferent $(\mathrm{M}=307$ and $\mathrm{SD}=1.039)$ whether they can write as if having conversation 
with another person. Further results showed learners agreed $(\mathrm{M}=3.98$ and $\mathrm{SD}=1.122)$ that they can vary punctuation marks on specific sentences and paragraph and learners also agreed $(\mathrm{M}=4.23$ and $\mathrm{SD}=1.479)$ that when writing they construct words and sentences that make good paragraphs.

The mean and standard deviation for revised strategy revealed $\mathrm{M}=3.86$ and $\mathrm{SD}=1.245$ which imply use of revised strategy contributes to learners achievement in composition writing skills in public primary schools. This finding agrees with Wiwiek et al (2010).

\section{Buzz Strategy}

The present analysis sought to find out the influence of buzz strategy on learners' achievement in composition writing. Findings for this analysis are shown in Table 4.4.

Table4.5:-Buzz Strategy Influence on Learners Achievement

\begin{tabular}{|l|l|l|}
\hline Strategy Statements & Mean & Std. Dev \\
\hline $\begin{array}{l}\text { While writing, I can identify different paragraphs in } \\
\text { a logical manner }\end{array}$ & 3.36 & 1.341 \\
\hline $\begin{array}{l}\text { When I write, I pause between the paragraphs for } \\
\text { snap checks of punctuation marks and spelling } \\
\text { checks. }\end{array}$ & 2.21 & 1.012 \\
\hline $\begin{array}{l}\text { While writing I still hesitate when I need to use } \\
\text { new words, similes or proverbs. }\end{array}$ & 4.52 & 1.952 \\
\hline $\begin{array}{l}\text { While writing, and come across difficulties in } \\
\text { connections of one paragraph to the other I hesitate } \\
\text { but manage to continue. }\end{array}$ & 3.34 & 1.209 \\
\hline Average Score & & $\mathbf{3 . 3 6}$ \\
\hline
\end{tabular}

Findings shown in Table 4.5 revealed learners strongly agreed $(\mathrm{M}=3.36$ and $\mathrm{SD}=1.341)$ that they can identify different paragraphs in a logical manner during writing composition. Similarly, learners disagreed $(\mathrm{M}=2.21$ and $\mathrm{SD}=1.012$ ) that they pause between the paragraph for snap checks of punctuation marks when writing. Additional findings revealed that they strongly agreed $(\mathrm{M}=4.52$ and $\mathrm{SD}=1.952)$ that they hesitate when needed to use new words, similes or proverbs when writing composition and learners were indifferent $(\mathrm{M}=3.34$ and $\mathrm{SD}=1.209)$ whether they can manage the difficulty in connecting paragraphs. These findings imply that learners can identify different paragraphs in a logical manner during writing composition, though they hesitate when needed to use new word, similes or proverbs when writing composition. In addition, learners do not pause between the paragraphs for snap checks of punctuation marks when writing and cannot manage the difficulty in connecting paragraphs.

The mean and standard deviation for buzz strategy revealed $\mathrm{M}=3.36$ and $\mathrm{SD}=1.379$. This implies teachers of English use of buzz strategy contribute to learners composition writing skills. The finding collaborates with Ni' Mah(2015) study which showed a significant strong positive correlation between buzz strategy and student's activeness and writing skills.

\section{Three Minutes Strategy}

The present analysis sought to find out the influence of Three Minutes strategy on learners achievement in composition writing. Findings are shown Table 4.5

Table 4.6:-Three Minutes Strategy Influence on Learners Achievement

\begin{tabular}{|l|l|l|}
\hline Strategy Statements & Mean & Std. Dev \\
\hline $\begin{array}{l}\text { While writing I still have difficulty in doing good paragraphs } \\
\text { SParagraphs bring good story line and concluding in order to } \\
\text { create a climax. }\end{array}$ & 3.45 & 1.128 \\
\hline I write consistently with a good speed & 3.62 & 1.112 \\
\hline I write slowly and with difficulty. & 3.11 & 1.901 \\
\hline I write with an uneven mixture of fast and slow. & 4.61 & 2.151 \\
\hline Average Score & & $\mathbf{3 . 4 0}$ \\
\hline
\end{tabular}


Findings shown in Table 4.6 revealed that learners agreed $(M=3.45$ and $\mathrm{SD}=1.128)$ that they do have difficulty in doing good paragraphs, bringing a good story line and concluding in order to create a climax. Learners also agreed $(\mathrm{M}=3.62$ and $\mathrm{SD}=1.112)$ that they write consistently with a good speed and learners were also indifferent $(\mathrm{M}=3.11$ and $\mathrm{SD}=1.901$ ) whether they write slowly and with difficulty. Further results showed that learners strongly agreed $(\mathrm{M}=4.61$ and $\mathrm{SD}=2.151)$ that they write with uneven mixture of fast and slow speed.

These findings imply that learners have difficulty in doing paragraphs, bringing a good story line and concluding in order to create a climax; learners can write consistently with a good speed or with uneven mixture of fast and slow speed. This finding agrees with Bello (2014).

\section{Hypothesis Testing for Small Group Technique}

This study sought to test the third Null Hypothesis $\left(\mathrm{HO}_{3}\right)$ which assumed no statistical significant relationship between small group technique and learners' achievement in composition writing skills in public primary schools in Kisumu County. The result for Z-test statistics are shown in Table 4.6.

Table 4.7:-z-Test for Small Group Techniques

\begin{tabular}{|r|r|r|}
\hline Technique & \multicolumn{2}{|r|}{ Experiment Group } \\
\cline { 2 - 4 } & z-Statistics & P-value \\
\hline Small group technique & 24.09581 & 0.0000 \\
\hline
\end{tabular}

Result from Table 4.7 revealed that the small group technique computed $\mathrm{z}$ statistic showed $\mathrm{z}=24.09581$ and $\mathrm{p}=0.0000$. The $\mathrm{p}$-value was less than the $0.05(\mathrm{p}<0.05)$ which is the bench mark value for rejecting the Null Hypothesis assuming 95\% significance level. Therefore, the study rejected that Null Hypothesis, as there was a statistically significant relationship between small group technique and learners' achievement in composition writing skills in public primary schools in Kisumu County.

\section{References:-}

1. Amaghawry, A. (2012). Effectiveness of Using the Brainstorming Technique to Learn Some Basic Skills and Collection of Knowledge for Beginners in Volleyball. World Journal of Sport Sciences 6 (4): 361 -366 arbu, R. \& Lucia (2007). Using Drama Techniques for Teaching English. Retrieved on 17/7/2010

2. Brown, J. D. (1995). The elements of Language curriculum: A system Approach to program Development. New York: Heinle and Heinle.

3. Carter, J. (2002). Creative ideas for writing.London: David Fultan

4. Cohen, L., Manion, L. \& Morrison, K. (2007).Research methods in education (6thedn.).London: Routledge.

5. David, M and Alexander, P (2013): Small Group Teaching; a toolkit for teaching. The Higher Academy

6. Dewey, J., (1993). Improving reading comprehension skills by using mind mapping software with students of bachelor's degree in English attending reading and writing in English II course at Universidad de OrienteUNIVO, San Miguel.Phd. Dissertation.Universidad de Oriente, San Miguel, El Salvador, Centro America.Education.

7. Fleming, M. (2006). "Drama and language teaching. The relevance of Wittgenstein's concept of language games". Humanizing language teaching, 2006, issue 4 retrieved fromhttp://www.hitmag.co.uk.jul06/martoi.htm

8. Heiman, G. (1999). Research methods in psychology. Boston: Houghton Mifflin Company.

9. Kenya National Examination Council, (2007-2013). Kenya Certificate of Secondary Examination.Nairobi: KNEC.

10. Martal, A. (2014). The Role of Computer Assisted Language Learning (CALL) for English Language learning of Elementary and High Schools In Indonesia in Journal Register volume 5, No. 2.

11. Patel, H. and Jain S. (2008).Qualitative interviews in psychology: Problems and possibilities. Qualitative Research in Psychology, 2: 281-307.http://dx.doi.org/10.1191/1478088705qp045oa

12. Piaget, J. \&Inhelder, B. (1969).The Psychology of the Child. London: Routledge\&Kegan Paul.

13. Stephen G \&Abrams, M.H. (2006).Twentieth Century Drama. The Natan Anthology of English Literature New York: Norton.

14. Vygotsky, L. (1978). Mind in Society the Development of Higher Psychological Process-Cambridge Mass: Harvard University Press.

15. Wiwiek et al, (2001).Small groups working techniques. In M. Celce-Murcia (Ed.), Teaching English as a second or foreign language (pp.187-203).US: HeinleHeinle. 